\title{
TOURIST VILLAGE PORTRAIT (CASE STUDY IN KAMPUNG TAJUR, DESA PASANGGRAHAN, KECAMATAN BOJONG, KABUPATEN PURWAKARTA)
}

\author{
Iyan Mugni Nugraha, Gunardi Judawinata \\ Universitas Padjadjaran \\ iyanmugni@gmail.com
}

\begin{abstract}
Kampung Tajur is located at the foot of Mount Burangrang Purwakarta, this area has beautiful natural scenery and cool air so that it has the potential to be used as a tourist destination. The purpose of this study is to find out the sustainability of Kampung Tajur as a tourist destination by conducting portraits wisely and based on relevant socio-economic theories. The design used is qualitative with a case study method. The results of the study show that based on the history of the chronicle and its development, Kampung Tajur has potential and has long been projected as a tourist destination. Based on their performance, Kampung Tajur tends to be categorized as a Tourism Village. Kampung Tajur is managed by the local community and the Tourism Driving Group. The Kampung Tajur management system tends to use the Top-down approach. The Kampung Tajur has several positive impacts on the economic and socio-cultural life of its people and has a negative impact, namely the decrease in the level of community harmony due to inequality in income. The sustainability of Kampung Tajur as a Tourism Village is poorly maintained due to several development efforts that tend to be less than optimal
\end{abstract}

\section{Keywords : Tourist Village, Kampung Tajur, Mount Burangrang}

\section{INTRODUCTION}

The Indonesian government is now intensifying the efforts to build a strong economy in various sectors. One of the sectors that can be utilized is the tourism sector. The tourism sector is expected to be able to improve the national and local economy, and encourage business opportunities for the surrounding society in order to recruit labor (Soebagyo, 2012).

In 2017, the tourism sector as the second largest foreign exchange contributor with a value of 190 trillion rupiah. The beauty of nature and the cultural wealth that Indonesia has can be a potential in the tourism sector. Natural resources and their ecosystems, the diversity of flora and fauna and natural phenomena with the beauty of pure views can be the attraction of a tourist attraction. 
The shifting of the concept of world tourism to special interest tourism, is known as ecotourism. Ecotourism can be a great opportunity for our country with its extraordinary natural potential. This because of the fact that many tourists tend to visit tourist objects based on the nature and the culture of local people. Wisata alam merupakan salah satu konsep pengelolaan pariwisata yang menyeimbangkan kepentingan ekonomi, sosial dan ekologis, konsep pengelolaan ini diharapkan mampu memperbaiki kerusakan lingkungan akibat pihak-pihak yang tidak bertanggung jawab dan mampu meningkatkan pendapatan dan kesejahteraan masyarakat sekitar kawasan (Marpaung, 2002)

West Java is one of the provinces that is the choice of tourists both local and foreign, one of which is in Purwakarta Regency. In accordance with one of the Purwakarta Regency long-term missions namely improving the economy of the community that is competitive and based on local potential, Purwakarta Regency promotes the development of the tourism sector.

Kampung Tajur is one of the tourist destinations in Purwakarta. Located at the foot of Mount Burangrang, Kampung Tajur offers the beauty of nature and cool air, so that it has the potential to become a tourist destination. The village of Tajur combines elements of agriculture, culture and local wisdom. Kampung Tajur is managed by the community and the Tourism Driving Group (KOMPEPAR). The purpose of a local management system is community empowerment. So that people can determine the quality of tourism products and attractions offered to tourists. The better the quality offered, the more likely it is for the community to improve their standard of living.

The number of tourists that come is one indicator of the quality offered. In fact, tourists visiting Kampung Tajur in 2018 experienced a decline from the previous year. This indicates that there is tourist dissatisfaction with the quality of tourism products offered by the community. Tourist dissatisfaction may also occur due to a less professional management system. If it is not immediately evaluated, then the sustainability of the Kampung Tajur tourist area will be adversely affected. To find out its sustainability, it is necessary to portray wisely based on the relevant socio-economic theory of Kampung Tajur as a tourist area.

\section{Tourism}

\section{LITERATURE REVIEW}

According to the Tourism Law No. 10 of 2009, tourism is a variety of tourism activities and is supported by various facilities and services provided by the community, businessmen, government, and local government. Tourism is an overall activity that is related to multidimensional and multidisciplinary tourism that emerges as a manifestation of the needs of every person and country as well as the interaction between tourists and the local community, fellow tourists, the government, regional governments and entrepreneurs.

\section{Tourism Village}

Nuryanti (1992) defines tourism villages as a form of integration between attractions, accommodations, and supporting facilities that are presented in a structure of community life that is integrated with prevailing procedures and traditions. It is also emphasized that the most important components in tourism villages are (1) accommodation, which is part of the residence of local residents and 
/ / units that develop in accordance with residents' dwellings, and (2) attractions, namely the entire daily life of local residents and their backgrounds physical village location that allows the integration of tourists as active participants, such as dance, language, painting, and other specific matters

\section{Tourist Attraction}

Tourist attraction is the main factor of tourists visiting a tourist attraction. According to the Law of the Republic of Indonesia No. 10 of 2009, "Attractiveness is a uniqueness, ease, and tangible value of diversity, natural wealth, culture, and man-made results that are the target for tourists". Not all solid tourist locations qualify to become tourist destinations. According to Yoeti (1996), tourist destinations must be supported by the attractiveness of 3A namely Attraction, Accessibility, and Amenities (Facilities).

\section{Top-down and Bottom-up Uproach in Management System}

According to Sabatier (1993), there are two types of approaches in management systems, namely the 'top-down' and 'bottom-up' approaches. The 'topdown' approach is identical to the implementation of policies, namely activities that are seen after the legitimate direction of a policy is issued which includes efforts to produce output or outcomes for the community. While the 'bottom-up' approach is synonymous with policy making, namely the policy process begins with the delivery of aspirations, requests or support from the community.

\section{Management Functions}

According to Sondang. P. Siagian in Hasibuan (2010), management functions include:

a. Planning (Planning) can be defined as the whole process of thought and careful determination of the things that will be done in the future in order to achieve the objectives that have been set.

b. Organizing is the whole process of grouping people, tools, tasks, responsibilities, and authority in such a way as to create an organization that can be mobilized as a unit in order to achieve the intended goals.

c. Motivating can be defined as the whole process of giving encouragement to work to subordinates in such a way that they want to work with sincerity in order to achieve organizational goals efficiently and economically

d. Supervision (Controlling) is the process of observing the implementation of all organizational activities to ensure that all work being carried out goes according to a predetermined plan.

e. Evaluation is the last organic function of administration and management. The definition is the process of measuring and comparing the results of work which in fact is achieved with the results that should be achieved.

\section{Tourism Impact}

The impact of tourism on the community and tourist destinations that receive many reviews is the impact on the economy, socio-culture, and environment (Sedarmayanti, 2014) 


\section{Economic Impact}

According to Retty (2007), economic impact is a change that occurs in society as a result of a relationship between one and the other that can be mutually beneficial or can harm one or the other.

\section{Socio-Cultural Impact}

Mathieson and Wall (1982) stated that "there is no clear distinction between social and cultural phenomena" so that most experts combine social impact and cultural impact into the title of social and cultural impacts.

\section{Law No. 29 of 1999}

To succeed in the development of tourist villages, efforts need to be taken as follows.

1. Development of Human Resources (HR)

2. Partnership

3. Government Activities in the Village

4. Collaboration with the University.

\section{METHODOLOGY}

This research used a qualitative design with a case research method. The informants are chosen by purposive sampling that were able to provide information related to this research, that is Pasanggrahan Village Apparatus, KOMPEPAR Management, Karang Taruna Chairperson, Kampung Tajur Community who participated in the management

The data collection techniques are important things that become a connector between researchers and the research objects and then generate the data. The technique used in this research is to collect data, that are:

1. Observation

2. Deep Interviews

3. Documentation Research

4. Studi Pustaka

According to Miles and Hubermen (in Satori and Komariah, 2017), the stages of processing and analyzing data in qualitative research, are:

1. Data Reduction

2. Data display

3. Conclusion Drawing / Verification

\section{History of Kampung Tajur}

\section{RESULTS AND DISCUSSION}

According to the stories of local elders, the word "Pasanggrahan" means stop. Philosophically and historically, Pasanggrahan village has the potential to become a tourist area. The village of Tajur Purwakarta began to be built as a tourist area starting in 2004. At that time, Deputy Regent of Purwakarta Dedy Mulyadi saw the 
potential of Kampung Tajur as a tourist area. Since 1995, the village of Pasanggrahan has been visited by tourists as a haven before climbing to Mount Burangrang. Kampung Tajur received 3 times assistance for the development of tourist areas in 2012, 2015 and 2016.

Judging from the history of its development, Kampung Tajur tends to be projected as a tourist area. Assistance provided by the government tends to be oriented towards matters relating to tourism. The development carried out was also oriented to tourism supporting infrastructure.

\section{General Overview Of Kampung Tajur Purwakarta}

Tajur Purwakarta Village is located in Pasanggrahan Village, Bojong District, Purwakarta Regency. The tourist area at the foot of the Burangrang mountain offers the beauty of nature and various tourist attractions that tourists can enjoy. In this place, the average tourist is a group that comes from the private sector, government agencies to educational institutions from the elementary school level to the university can feel and study the lives of rural communities. Starting from the culture that is still maintained for generations until the natural conditions are still beautiful and not polluted. The people of Kampung Tajur maintain the condition of the rivers, rice fields and hills around them. They believe that caring for nature is the same as caring for their lives, including saving the next generation from the destruction of nature

Kampung Tajur is managed by local communities with assistance from the village-level Tourism Driving Group (KOMPEPAR). Managed from the community, by the community and for the community. So that this tourist area can bring economic benefits to the people. That is in the form of additional income from the homestay rent and from participation in the tour packages offered. In general, the facilities owned by Kampung Tajur consist of 1 Jami Mosque, 3 Bath Washing Public latrines, 1 large room, several fish pond blocks, 1 meeting hall, 1 sample house and several blocks of rice fields for tourist education.

Agricultural education is an integral part of Kampung Tajur. Tourists can learn to plant, care for plants, plow fields, to reap their crops to be consumed directly. During their stay at the homestay, tourists will take part in the daily activities of foster parents whose jobs vary. Some raise fish in ponds, grow vegetables, and plant rice in the fields. Besides that tourists can also learn how to make Kampung Tajur specialties namely wajit, cassava chips, and palm sugar and learn to make handicrafts from used goods. Food obtained from these learning outcomes can be consumed directly on site. The tariff for each package varies between Rp. 300,000 - Rp. 500,000. Sometimes there are also some tourists tracking around Kampung Tajur tourist area. Based on their performance, Kampung Tajur tends to be categorized as a Tourism Village. 


\section{Tourist Attraction}

(1) Attractions

Table 1. Types of Attractions in Kampung Tajur

\begin{tabular}{|c|c|c|}
\hline \multirow[b]{2}{*}{ Tourism Village } & \multicolumn{2}{|l|}{ Attraction } \\
\hline & Objects that can be seen & $\begin{array}{l}\text { Activities that can be } \\
\text { done }\end{array}$ \\
\hline Kampung Tajur & $\begin{array}{l}\text { 1)View of the Ciherang River, } \\
\text { Fish Pond and Rice Fields } \\
\text { 2) View of Mount Burangrang } \\
\text { 3) Sundanese Traditional Stage } \\
\text { Houses Julang Ngapak } \\
\text { (Homestay) }\end{array}$ & $\begin{array}{l}\text { 1) Take a photo } \\
\text { 2) Overnight at the } \\
\text { Homestay stage house } \\
\text { 3) Playing on the river } \\
\text { 4) Catch and burn fish } \\
\text { from the pond } \\
\text { 5) Plowing fields using } \\
\text { buffalo } \\
\text { 6) Making handicrafts } \\
\text { from used goods } \\
\text { 7) Making traditional } \\
\text { foods typical of Kampung } \\
\text { Tajur }\end{array}$ \\
\hline
\end{tabular}

\section{(2) Accessibility}

Table 2. Accessibility of Kampung Tajur

\begin{tabular}{|l|l|}
\hline Tourism Village & Accessibility \\
\hline & $5 \mathrm{~km}$ or \pm 1.5 hours from downtown Purwakarta. \\
& The road narrowed and steep when entering Cihanjawar \\
Kampung Tajur & $\begin{array}{l}\text { The majority of road conditions are good with conditions } \\
\text { already paved } \\
\text { There are no public transportation } \\
\text { Can't pass big bus }\end{array}$ \\
\hline
\end{tabular}

\section{(3) Amenities}

In Kampung Tajur there are already electricity networks and communication networks. For communication networks, such as telephone signals are good enough for some providers, especially Telkomsel. Clean water is also available well. Around the village of Tajur there are also many infrastructure needs of the community such as health centers, gas stations, post offices, markets and banks. The infrastructure is available in the Wanayasa market area, which is about 5 kilometers from Kampung Tajur. The tourist facilities offered are homestays, food stalls, fields, Jami Mosque, meeting halls, and sample houses.

\section{Kampung Kampung Tajur Tourism Management System}

The Approach to Management of the Village Tourism Village of Tajur

Based on the management method, it can be said that the management system in Kampung Tajur Tourism Village tends to use the Top-down approach. The role of the community and managers is still limited to implementing policies. Things that are of a strategic nature are still determined by the center of policy makers in 
this case the Purwakarta Regency government. This is certainly not good for the continuity of the Village Tourism Village of Tajur because it is very vulnerable to other interests such as political motives. One indication of the adverse effects of the Top-down approach is the decreasing number of tourists visiting from 2017 to 2018 (see table 4). Although many things affect the decline in the number of tourists, the management system needs to be suspected as one of the contributing factors.

\section{Management Functions in the Management of the Village Tourism Village of Tajur}

The Kampung Tajur Tourism Area is fully managed by the Pasanggrahan Village Tourism Group and the local community. According to Mr. Syarif as the Secretary of KOMPEPAR Pasanggrahan Village, the manager of Kampung Tajur never held regular meetings or discussions that discussed specific issues such as annual targets or long-term programs. The meeting was carried out only when they wished to welcome a group of tourists who usually carried out h-3 visits. The aim is to prepare themselves so that groups of tourists feel satisfied with the services provided. That's when the manager uses management functions in the form of planning, organizing, mobilizing, monitoring and evaluating

\section{Social And Economics Impact}

The development of Kampung Tajur as a Tourism Village has an impact on the economic and socio-cultural fields. In the economic field, Kampung Tajur has a positive impact in the form of increasing income, expanding employment, but not with village income. In terms of socio-culture, Kampung Tajur has a positive impact in the form of community interaction with tourists and the level of mutual cooperation. Its existence raises income injustice among the people. Especially between the people whose location is near the field with those who are far from the field.

\section{Sustainability of Kampung Tajur as a Tourism Village}

Kampung Tajur almost fulfills all the requirements as a tourist village in accordance with the contents of Law No. 29 of 1999. In the regulation also explained that the sustainability of a Tourism Village depends on its development efforts. Kampung Tajur tends to have made a maximum effort in the development of Human Resources (HR) and government activities in the village. In other cases, partnerships, promotions, festivals and collaboration with universities tend to be less than optimal. The sustainability of Kampung Tajur tends to be poorly maintained. This is caused by several development efforts that tend to be less than optimal.

\section{CONCLUSION AND SUGGESTION}

\section{CONCLUSION}

Sustainability of Kampung Tajur as a Tourism Village is poorly maintained due to several development efforts tend to be less than optimal. Historically, Kampung Tajur has potential and has long been projected as a tourist destination. Based on their performance, Kampung Tajur tends to be categorized as a Tourism 
Village. The Kampung Tajur Tourism Village is managed by the local community accompanied by the Tourism Driving Group (KOMPEPAR). The Kampung Tajur Tourism Village management system tends to use the Top-down approach. Kampung tourism area manager Tajur runs management functions in providing service to groups of tourists. The aim is to give satisfaction to the group of tourists.

\section{SUGGESTION}

Based on the conclusions above, suggestions can be given for the development of the tourism area of Kampung Tajur:

1. Managers must be more vigorous in carrying out promotions especially through social media. Managers already have social media accounts on Facebook, Instagram and Twitter, but the content is not informative so it is difficult to attract the attention of prospective tourists.

2. It is necessary to organize an event more often that can attract the attention of prospective tourists and do not rely on events organized by the department of culture and tourism Purwakarta district. Organizing the event can be started from simple things like festivals, traditional arts competitions or traditional craft creation competitions.

3. Managers should target and plan futures from the short, medium to long term. This is needed so that Kampung Tajur has a clear direction for future development.

\section{REFERENCE}

Hasibuan, M. 2015. Manajemen Dasar Pengertian dan Masalah. Jakarta: Bumi Aksara

McEwen, Thaddeus. 2013. Ecopreneurship as a Solution to Environmental Problems: Implications for College Level Entrepreneurship Education. Jurnal.

Nuryanti, W. 1996. Heritage and postmodern tourism, Annals of Tourism Research. doi: 10.1016/0160-7383(95)00062-3

Retty. (2007). MASYARAKAT ADAT SUNDA WIWITAN Jurnal Masyarakat \& Budaya. Bandung.

Sabatier, Paul A. 1993 Top-Down and Bottom-Up Approaches to Implementation Research: A Critical Analysis and Suggested Synthesis. Journal of Public Policy.

Satori, D. dan Komariah, A. 2017. Metodologi Penelitian Kualitatif. Bandung: Penerbit Alfabeta.

Sedarmayanti. 2009 PENGEMBANGAN FASILITAS WISATA AGRO ( Studi Kasus di Kebun Wisata Pasirmukti , Bogor ). Jurnal Manajemen dan Kewirausahaan. Jakarta.

Soebagyo. 2012. Strategi Pengembangan Pariwisata di Indonesia. Jurnal Universitas Pancasila, Jakarta Selatan.

Undang-undang Kepariwisataan No. 10 tahun 2009

Undang-undang No. 22 Tahun 1999

Yoeti. O. A. 1996. Pengantar Ilmu Pariwisata. Bandung : Penerbit Angkasa. 